\title{
BOOKS AND PUBLICATIONS OF THE DAY.
}

From Miss Jennie McCowen, A.M., M.D. 1. An address before the Medical Alumni of the Iowa State University. "Duties of the profession in relation to insanity." 2. "The prevention of insanity;" read before the National Conference at Madison, Wisconsin. 3. "Psychiatry in Iowa."

Miss Jennie McCowen, at the last meeting of the State Medical Society, was chosen President, the first of the sex to be placed in that position. The above tracts from her pen show, upon perusal, that she is becoming well informed with respect to the matter of insanity, increasing as it is and tending to suicide, which also is a growing, pernicious evil. Miss McCowen might well lecture on this subject, which she seems to be mastering, in our medical and other institutions of learning, in regard to which there is much need of further legislative action, as she intimates.

"Fetish in theology," by Rev. John Miller, D.D., Princeton, N. J. This volume is a strange and singular work. It attacks Rev. Dr. Hodge's theology, discards the glory of God as the highest motive of the Deity in governing the universe, and substitutes righteousness instead of it. He undertakes to show fetishism in a variety of forms in the received theology of the age. The limits of this publication will not allow an extensive review nor controversy, as it is historical, and can state only facts. Dr. Miller is somewhat original in his representation and thinking, but Dr. Samuel Miller, his father, would, if living, discard many of his theological novelties, especially his views of the Holy Trinity.

Missionary Review, by Rev. Royal G. Wilder, a missionary, returned from Kolapoor, India, is a treasury of missionary statistics, and would be more interesting to common readers, if the editor inserted more stirring extracts of what is going on in the various missions. His mind rather runs to statistical matters. We have noticed it favorably before, but do not find any notice in it of our remarks upon the management of the Review. 
Copyright of Annals of Iowa is the property of State of Iowa, by \& through the State Historical Society of Iowa and its content may not be copied or emailed to multiple sites or posted to a listserv without the copyright holder's express written permission. However, users may print, download, or email articles for individual use. 